\title{
THE IMPACT OF ARREST RECORDS ON THE EXERCISE OF POLICE DISCRETION
}

I

INTRODUCTION

Arrest records play a significant role in today's society. Millions of arrest records exist for Americans and an estimated nine million records are added each year. ${ }^{1}$ The President's Commission on Law Enforcement and Administration of Criminal Justice estimated in 1968 that 52,000,000 records existed and that from forty to fifty percent of the male population over the age of eighteen would, at some time in their lives, be arrested for a nontraffic offense. $^{2}$

The records reflect a multitude of offenses and alleged offenses and are often incomplete, inaccurate or misleading. ${ }^{3}$ These records, however, are used by law enforcement agencies, government entities, and even prospective employers as a prime source of information about individuals. This note focuses on the significance of arrest records as an influence on the exercise of police discretion. The note defines the issues surrounding police use of arrest records, addresses some of the concerns related to the use of such records within the broader context of the norms of the criminal justice system, and suggests areas for future study.

The popular and legal literature notes many examples of the deleterious use by the police of the information contained in arrest records, at least with respect to the individuals immortalized in such records. ${ }^{4}$ Underlying this literature are persistent questions regarding the propriety of retaining, disseminating, and utilizing arrest records. The desire to ensure that the law enforcement system does not use arrest records to contravene the accepted norms of the criminal justice system must, of course, be balanced against the

Copyright $(\mathcal{O} 1984$ by Law and Contemporary Problems

1. Neier, Introduction to T. Ballinger, CleEan Slate 7 (1979).

2. See United States v. Benlizar, 459 F. Supp. 614, 620 (D.C. Cir. 1978).

3. Ballinger estimates that $65 \%$ of arrest records are incomplete or inaccurate. T. BALLINGER, supra note 1 , at 29.

4. For examples, see Davis, Records of Arrest and Conviction: A Comparative Study of Institutional Abuse, 13 Creighton L. Rev. 863 (1980); Karabian, Record of Arrest: The Indelible Stain, 3 PAC. L.J. 20 (1972); Note, Discrimination on the Basis of Arrest Records, 56 Cornell L.Q. 470 (1971); Note, Constitutional Law-Right of Police to Retain Arrest Records, 49 N.C.L. REv. 509 (1971); When Nightmare of False Atrest Comes True, U.S. News \& World ReP., Dec. 17, 1984, at 45. 
legitimate interests of police administrators in obtaining as much information as possible about alleged offenders to maximize the effectiveness of their departments.

Law enforcement agencies argue that the availability and use of arrest records assist investigations and permit officers to have a broader understanding of the individual under investigation. Consequently, agencies claim that the records are a legitimate tool for making distinctions in situations in which full enforcement is not the standard. ${ }^{5}$ In the absence of such information, the claim is that police officers would either have to arrest everyone suspected of an infraction or resort to other types of information, perhaps more biased and less indicative of criminality, in deciding which suspects to arrest. ${ }^{6}$ In addition, police agencies claim that these records are needed to combat recidivism, especially by more mobile offenders, but the data supporting this contention are scant. ${ }^{7}$ Furthermore, these arguments implicitly assume that records of arrest are valid predictors of criminal behavior.

The ways in which arrest records are used reflect the type of law enforcement system employed in a society. Herbert Packer, in discussing various possibilities for law enforcement systems, set forth the following as polar models:

The Crime Control model sees the efficient, expeditious, and reliable screening and disposition of persons suspected of crime as the control value to be served by the criminal process. The Due Process model sees the function as limited by and subordinate to the maintenance of the dignity and autonomy of the individual. ${ }^{8}$

In reality, the American law enforcement system does not fit exactly into either model, but instead lies somewhere along a continuum between the two. The rules chosen for the system help to shape its priorities and, in turn, force the system to move closer to one or the other model.

Arrest records are one of many tools for law enforcement, and the more extensive the tools, the more the system will resemble the Crime Control model. Conversely, the more the tools of law enforcement agencies are restricted, either legislatively or judicially, the greater will be the resemblance to the Due Process model. The premise of this note is that arrest records are an increasingly effective tool for law enforcement agencies and that,

5. See generally Goldstein, Police Discretion Not to Invoke the Criminal Process: Low-Visibility Decisions in the Administration of Justice, 69 YALE L.J. 543, 561-62; Monroe v. Tielsch, 84 Wash. 2d 217, 219,525 P.2d 250, 251 (1974).

6. See Goldstein, supra note 5, at 561-62.

7. See J. Murphy, Arrest by Police Computer 7 (1975).

8. Packer, The Courts, the Police, and the Rest of Us, 57 J. Crim. L., Criminology \& Police Sci. 238, 239 (1966). One author sees these models as

competing ideological visions of how our system serves criminal procedurse's functions. Both models describe a set of values, beliefs, attitudes, and ideas about our criminal justice system that are held by many legal actors within the system and that are reflected in some of its institutions and practices .... [B]oth ideological models provide a source for legitimate arguments that courts may use to shape legal doctrine in criminal procedure.

Arenella, Rethinking the Functions of Criminal Procedure: The Warren and Burger Courts' Competing Ideologies, 72 GEO. L.J. 185, $188-89$ (1983). 
depending upon the model of preference, some controls over the use of these records may be necessary.

The proper use of arrest records in the exercise of police discretion is important since the problems associated with the use of such records are likely to be exacerbated by the modernization and computerization of the criminal recordkeeping system. The National Crime Information Center (NCIC) is already the depository of millions of records, and an increasing number of police departments are tying into its system. ${ }^{9}$ One court has referred to the mushrooming police records as a system "out of effective control," especially in light of the FBI's failure to ensure the accuracy of the information. ${ }^{10}$ Furthermore, the widespread use of arrest files by the police may be viewed as a form of "dependency." 11 If police personnel can readily obtain information relating to an individual's arrest history, that information is likely to play a greater role in the exercise of discretion in the field. As a result, the risk that an individual's immediate fate will be influenced by events which have little relevance to his current situation or criminality increases dramatically.

\section{II}

\section{The Definition and Availability of Arrest Records}

Any discussion of the use of arrest records in the exercise of police discretion must begin with a definition of arrest records. Arrest records are those records maintained by law enforcement agencies detailing incidents of arrest or detention by police authorities. For purposes of this note, a paradigmatic case is established: the individual who is arrested but is neither convicted nor the beneficiary of a preprosecution diversion program. This model is utilized because it represents the individual most likely to be harmed by the existence and availability of arrest records. The problems associated with the use of arrest records with regard to this individual are not unique, however, but are applicable to some degree to all persons with prior arrest records.

Arrest records are normally available to law enforcement authorities. Most legislatures have placed few, if any, meaningful limitations on access to these records, ${ }^{12}$ thereby accommodating the interests of law enforcement agencies in maintaining and using records of arrest. ${ }^{13}$

Simultaneously, courts have taken a narrow view of their authority to impose restrictions on access to and use of arrest records. ${ }^{14}$ In the absence of legislatively mandated solutions, courts must rely on their equity powers,

9. See generally Davidson v. Dill, 180 Colo. 123, 126, 503 P.2d 157, 159 (1972); Smith, Wehmeyer, Keating \& Berberich, Background Information: Does It Affect the Misdemeanor Arrest? $4 \mathrm{~J}$. PoL. ScI. \& AD. 111 (1976).

10. Menard v. Saxbe, 498 F.2d 1017, 1026 (D.C. Cir. 1974).

11. J. Murphy, supra note 7 , at 5 .

12. See, e.g., State v. Nettles, 375 So. 2d 1339, 1341 (La. 1979).

13. Legislatures have become more sensitive to privacy interests in the last few years, creating the potential for restricting the wide-open use of arrest records.

14. See, e.g., United States v. Singleton, 442 F. Supp. 722, 723 (S.D. Tex. 1977). 
which are used to address only the most blatant cases of abuse associated with the records. In extreme cases, usually involving mass arrests or egregious constitutional violations, courts have stepped in to assist an individual. ${ }^{15}$ Courts will usually order expungement of the record in such cases. ${ }^{16}$ This judicial power, though, is of limited value, since most courts agree with the Second Circuit Court of Appeals' conclusion that "the power to expunge 'is a narrow one, and should not be routinely used whenever a criminal prosecution ends in an acquittal but should be reserved for the unusual or extreme case." 17 Thus, courts typically treat the expungement remedy as a narrow and greatly circumscribed power. Even those courts which grant this remedy more freely are limited in their ability to control the damage caused by these records; because the dissemination of information in police records is so widespread and so rapid, courts may not be able to undo all the harm, or even the most significant harm, associated with the use of such records. ${ }^{18}$ In addition, some courts which permit expungement of arrest records put the burden on the arrestee-defendant to prove affirmatively that he was not guilty of the crime charged. ${ }^{19}$

Courts thus continually condone the availability and use of arrest records. Even in cases resulting in acquittal, courts often hold that arrestees are not entitled to a return of their arrest records. ${ }^{20}$ The records are therefore often inaccurate indicators of criminality, and the criminal justice system, by making the records freely available, perpetuates any misperceptions associated with them. ${ }^{21}$

15. See, e.g., Menard v. Mitchell, 430 F.2d 486, 493-94 (D.C. Cir. 1970); In re R.L.F., 256 N.W.2d 803, 807 (Minn. 1977).

16. E.g., Sullivan v. Murphy, 478 F.2d 938, $968-69$ (D.C. Cir. 1979), cert. denied, 414 U.S. 880 (1973); Wheeler v. Goodman, 306 F. Supp. 58 (W.D.N.C. 1969) (three-judge panel); Hughes v. Rizzo, 282 F. Supp. 881 (E.D. Pa. 1968).

17. United States v. Schnitzer, 567 F.2d 536, 539 (2d Cir. 1977) (quoting United States v. Linn, 513 F.2d 925, 927 (10th Cir.)), cert. denied, 423 U.S. 836 (1975); see also United States v. Singleton, 442 F. Supp. 722, 729 (S.D. Tex. 1977); United States v. Dooley, 364 F. Supp. 75, 78 (E.D. Pa. 1973); Spock v. District of Columbia, 283 A.2d 14, 17 (D.C. 1971).

18. See, e.g., McKnight v. Webster, 499 F. Supp. 420, 422 (E.D. Pa. 1980) (inaccurate records were in government files but no direct cause of action was permitted against the agency because it did not generate the information).

19. See Spock v. District of Columbia, 283 A.2d 14, 19 (D.C. 1971) (basis of relief is an uncontroverted showing of absence of culpability, as opposed to "mere exoneration"). The attitude of many courts was summed up in People v. Griffin, 32 Cal. Rptr. 24, 29, 383 P.2d 432, 437 (1963): "An acquittal is merely an adjudication that the proof at the prior proceeding was not sufficient to overcome all reasonable doubt of the guilt of the accused."

20. See cases cited supra note 17; see also District of Columbia v. Hudson, 404 A.2d 175, 179 (D.C. 1979)

21. The prior discussion focused on cases in which a record of arrest is created and no conviction results. In contradistinction are those cases where no record is created because it serves some purpose of a law enforcement agency. This event most often occurs when the police want an individual to serve as an informant. Reiss, Discretinary Justice in the United States, 2 INT'L J. Criminolocy \& Penology 181, 193 (1974); W. LaFave, Arrest: The Decision to Take a Suspect into Custody 493 (1965). In these situations, one major difficulty is that "above all there is an implied understanding between the policeman and the informant that the policeman will protect the informant's criminal status." J. Skolnick, Justice Without Trial 132 (2d ed. 1975). Besides the questionable desirability of having police protect criminal enterprises, there is the perverse result that known 


\section{Circumstances in Which Police Discretion May be Exercised}

Traditionally, commentators have focused on the legitimacy, ${ }^{22}$ efficacy, ${ }^{23}$ or availability of police discretion. ${ }^{24}$ But no study has examined the effects of police discretion on either rates of criminality or the efficiency of law enforcement agencies. To a large extent, this phenomenon may be a consequence of the virtual "invisibility" of these discretionary actions; ${ }^{25}$ few "beneficiaries" of the exercise of discretion (individuals that are not arrested) would challenge the decision of an officer to forego writing a ticket or to let a petty offender go free, and most nonbeneficiaries (individuals that are arrested) are hardpressed to complain of their arrest for a crime if there is ample evidence to support the charge and no intervening constitutional defect. ${ }^{26}$ Yet, as has long been recognized, the very exercise of discretion carries with it the possibility of capriciousness and discrimination, since few external checks are available. Even when such checks are available, they are seldom truly effective in the absence of expansive and costly supervision. ${ }^{27}$

Field work presents the initial opportunity for an officer to exercise discretion. The police officer at the street level is the first judge and jury for a potential arrestee. ${ }^{28}$ An individual may be ignored, merely warned, taken to the station for a "talk," or arrested. The officer's ultimate decision is not made in a vacuum, but rather depends upon a variety of factors including the availability of witnesses, the existence and credibility of a complaining party, ${ }^{29}$ the attitude of the suspect, the egregiousness of the offense, and the location. ${ }^{30}$ Information available to an officer is therefore at a premium, and the type and quality of information will influence, if not dictate, the decision made. $^{31}$ The determination of whether the information used by the officer should be restricted to what is available in the field or discoverable by

criminals are protected, both directly and indirectly by virtue of a clean record, while innocent individuals who are not useful as informants suffer the disabilities resulting from a criminal record. While within the confines of a small town or a restricted area this distinction might not mean much, given that the police will know the informant/criminal, the significance of this dichotomy is demonstrated when individuals move somewhere else. In the new location where neither innocent arrestee nor informant/criminal is known, authorities will have only their records on which to proceed. This possibility of different treatment underscores the questionable validity of permitting arrest records to influence police discretion.

22. K. Davis, Discretionary Justice (1969).

23. See Reiss, supra note 21; see also Smith \& Visher, Street-Level Justice: Situational Determinants of Police Arrest Decisions, 29 Soc. Probs. 167 (1981).

24: Goldstein, supra note 5 , at 543.

25. See id. at 552 .

26. Prerequisites for a valid arrest include either the existence of probable cause or the observation of a crime by an officer. The former is problematic, as discussed later, since the constituent parts of a probable cause finding may involve inappropriate factors.

27. See, e.g. W. LAFAVE, supra note 21 , at 136-37, 494.

28. See Davis, supra note 4 , at 874.

29. See Uviller, The Unworthy Victim: Police Discretion in the Credibility Call, Law \& Contemp. Probs., Autumn 1984, at 15.

30. Smith \& Visher, supra note 23, at 168-69.

31. See generally Sullivan \& Siegell, How Police Use Information to Make Decisions, 18 Crime \& DELINQ. 253 (1972). 
detective work, or whether external information, such as the suspect's arrest record, should also be utilized, necessarily affects the exercise of discretion. The imposition of controls on an officer's personal knowledge cannot be realistically effected. Controlling an external factor such as the availability and use of arrest records, however, can be done effectively and can have practical significance.

The police may also exercise discretion with respect to internal dispostions once an alleged offender is brought to the station house. ${ }^{32}$ The police may, for example, accept information from the detainee and in exchange forego his arrest, as is the case with informants. They may also decide not to file a charge against a first-time juvenile offender. In other situations, police use a trip to the station simply as a way of shaking up the detainee, hoping ultimately to set him on a more law-abiding path. The variations are extensive, and the situation not wholly different from the exercise of discretion in the field. In both circumstances, the presence or absence of an arrest record may influence the disposition of the matter. ${ }^{33}$

To a large extent, the conduct of an investigation is also a product of discretion. Police may choose not to emphasize the investigation of violations of certain criminal statutes and, by benign neglect, affect the enforceability of those laws. Officers may, as is the case with informants, choose to forego arrest for promising leads on known offenders. ${ }^{34}$ While the conduct of investigations certainly relates to a number of different factors-including political decisionmaking and public opinion-it is still, in the final analysis, a discretionary activity of the police. ${ }^{35}$

The use of discretion has the greatest significance at the point when the police are prepared to take affirmative action against a suspect. Although the initiation of arrest procedures might be thought to be mandatory at this point, at least when a crime has been observed, this is apparently not the case. Discretion is exercised both when a crime is observed and when the police, by investigation, have acquired enough information to have probable cause to arrest: "At law in the United States, the police have the authority to decide when there is probable or reasonable cause to believe that a crime has been committed. . . . Although the discretion to arrest is legally restricted, in practice, when enforcing the law, the police exercise enormous discretion to arrest." 36

32. See Monroe v. Tielsch, 84 Wash. 2d 217, 220, 525 P.2d 250, 251 (1974).

33. See, e.g., Loder v. Municipal Court, 17 Cal. 3d 859, 866, 553 P.2d 624, 629, 132 Cal. Rptr. 464, 469 (1976), cert. denied, 429 U.S. 1109 (1977).

34. See Eddy v. Moore, 5 Wash. App. 334, 342-43, 487 P.2d 211, 216 (1971); Davidson v. Dill, 180 Colo. 123, 127, 503 P.2d 157, 159 (1972).

35. See Goldstein, supra note 5, at 552; Reiss, supra note 21, at 192.

36. Reiss, supra note 21 , at 191 . 


\section{The Use of Arrest Records in Finding Probable Cause}

The finding of probable cause is the predicate to charging a suspect with an offense. The availability of arrest records affects the exercise of discretion in the determination of whether probable cause exists to the extent that it affects the information available to an officer. Arrest records (as well as the officer's personal knowledge) are therefore significant because they may swing a decision in favor of finding probable cause. ${ }^{37}$ An officer's finding of probable cause and an arrest based on that finding should logically have value only in the context of these initial events. Yet, subsequent arrests premised on a prior arrest allow, in essence, a street-level review of the earlier disposition. Although the existence of a prior arrest record alone is clearly insufficient to make out probable cause, the weight given to such records is more than de minimis. ${ }^{38}$ Moreover, even if an individual is ultimately dismissed from police custody with no formal charges having been brought, the arrest record remains. The justification for the use of arrest records for purposes such as the determination of probable cause is often based on the following premise:

With regard to the question whether the court properly considered information regarding an arrest upon which no charges were filed, we recognize that an arrest, without charge, trial, and conviction, is not proof of guilt. It is, however, evidence that the arresting officer considered that he had probable cause to make the arrest. The occurrence is one which has some relevance to the question before the court . . . 39

The Supreme Court has been unclear regarding the weight properly given to prior arrests in subsequent events. While the Court, in a case involving a lawyer's admittance to a state bar association, stated that a prior arrest had no probative value ${ }^{40}$ federal courts have approved the use of prior arrests in a number of different contexts, including sentencing, ${ }^{41}$ bail, ${ }^{42}$ and probable cause hearings. ${ }^{43}$ Even though the Supreme Court has not directly addressed the propriety of the use of arrest records in the field, it is reasonable to assume that their use would be upheld, given their accepted use in probable cause hearings. Approval of an officer's use of personal knowledge in securing a warrant also supports this conclusion. ${ }^{44}$ Furthermore, since the test for probable cause to arrest is the same as the probable cause standard applied in a preliminary hearing, and since the latter permits the consideration of inadmissible evidence, it is logical that in the former arrest records

37. W. LAFAVE, supra note 21, at 288.

38. See Beck v. Ohio, 379 U.S. 89, 97 (1964); see also People v. Martin, 9 Cal. 3d 687, 511 P.2d 1161, 108 Cal. Rptr. 809, cert. denied, Martin v. California, 414 U.S. 1113 (1973).

39. State v. Dainard, 85 Wash. 2d 624, 628, 537 P.2d 760, 762 (1975); see also Jones v. United States, 307 F.2d 190 (D.C. Cir. 1962), cert denied, 372 U.S. 919 (1963).

40. Schware v. Board of Bar Examiners, 353 U.S. 232, 241 (1957).

41. Williams v. New York, 337 U.S. 241 (1949); see also Jones v. United States, 307 F.2d 190, cert. denied, 372 U.S. 919 (1963).

42. Rhodes v. United States, 275 F.2d 78 (4th Cir. 1960).

43. Brinegar v. United States, 338 U.S. 160 (1949).

44. See United States v. Harris, 403 U.S. 573 (1971) (plurality decision). For data concerning the use of records in probable cause determinations, see Beck v. Ohio, 379 U.S. 89,97 (1964). 
should be an acceptable factor for consideration. ${ }^{45}$ In addition to the federal cases, numerous state court decisions have implicitly approved the use of arrest records in field-level determinations of probable cause. ${ }^{46}$

Police agencies have clearly taken advantage of the implicit authorization to use arrest records, and some agencies have codified this implied power. A model handbook developed under the auspices of the now defunct Law Enforcement Assistance Agency (LEAA) states: "A person's previous record can be considered along with other information in determining if there is probable cause to arrest him for a particular crime. . . . [I]nformation may be combined with a person's record to give probable cause." 47 This policy is also embodied in the Model Rules for Arrests developed by the Project on Law Enforcement Policy, ${ }^{48}$ which provides that: "Some of the purposes for which release of arrest and conviction information may be made to criminal justice personnel are: (i) in deciding whether to charge an individual with an offense; . . . (iii) in deciding whether to arrest or to summon . . . ."49

Even more important than the existence of such authorizations to use arrest records in the exercise of police discretion are the indications that arrest records actually do affect its exercise. A study of officers in Bellevue, Washington, found that with respect to misdemeanant offenders: "When the officer received unfavorable information [defined as information revealing prior arrests exclusive of traffic and juvenile drunk and disorderly offenses] he was more likely to complete an arrest than when he received favorable information." 50 The researchers actually found the disparity to be quite significant, concluding: " $[G]$ iven a misdemeanant crime situation in which the officer has marginal probable cause to make an arrest, the decision to arrest or release is decidedly influenced by the background information supplied to that officer through record checks. ${ }^{51}$

Two other studies support the findings of the Bellevue project. The first study observed officers in the field and found that, while a variety of factors influence the charging decision, the existence or lack of prior arrests had a

45. See Y. Kamisar, W. LaFave \& J. Israel, Modern Criminal Procedure 989-90 (5th ed. 1980 )

46. See, e.g., People v. Buchanan, 26 Cal. App. 3d 274, 103 Cal. Rptr. 66 (1972) (use of prior arrests in probable cause decisions); State v. Nettles, 375 So. $2 d 1339$ (La. 1979) (use of prior arrests in bond decisions); People v. Morales, 259 Cal. App. 2d 290, 66 Cal. Rptr. 234 (personal knowledge of officer about defendant relevant), cert. denied, 393 U.S. 988 (1968). One court has stated: "At the very least, the suspicion thus focused will justify additional investigation. If it is coupled with independent evidence of criminal involvement it may amount to probable cause to arrest . . . ." Loder v. Municipal Court, 17 Cal. 3d 859, 866, 553 P.2d 624, 629, 132 Cal. Rptr. 464, 469 (1976).

47. L. Schwartz \& S. Goldstein, Police Guidance Manuals: A Philadelphia Model 24 (1968).

48. Model Rules: Release of Arrest and Conviction Records (Project on Law Enforcement Policy and Rulemaking 1974).

49. Id. at 23.

50. Smith, Wehmeyer, Keating \& Berberich, supra note 9, at 113. Admittedly, other factors such as the race and attitude of the potential arrestee, as well as the officer's experience, may affect the officer's determination. See Pepinsky, Better Living Through Police Discretion, Law \& Contemp. Probs., Autumn 1984, at 249.

51. Smith, Wehmeyer, Keating \& Berberich, supra note 9, at 113. 
substantial impact on the officers' decisions. ${ }^{52}$ The second study, which focused on the decisionmaking of officers with differing experience and backgrounds, found that most officers give even greater weight to arrest records than to their own personal knowledge about a suspect. ${ }^{53}$ These studies are not determinative across localities, nor in their application to all types of offenses. The results are instructive, nonetheless, since they substantiate what has long been presumed-that police officers use prior arrest records as a determinant in arrest and charging decisions.

It is apparent that police officers do not feel restrained in their utilization of arrest records since their use is explicitly advocated by law enforcement agencies and implicitly sanctioned by the courts. Arrest records, though, are not a product of investigatory work relating to the crime at hand. Rather, they are independent and, usually, unrelated to the offense. Discretion is thus influenced by the entirely external factor of arrest records which, as will be shown, may not have any real significance to the criminality of the individual under investigation.

\section{The Predictive Validity of Arrest Records}

The significance of a record of arrest can vary greatly from case to case, since the record can result from a number of very different dispositions. A detainee may be arrested and convicted, arrested with probable cause but not convicted, or arrested without probable cause and not convicted-as in dragnet or mass arrest cases-or arrested and not convicted because of some technical problem involving the exclusionary rule. ${ }^{54}$ Society, however, gives great weight to the mere occurrence of an arrest.55 The types of inquiries made on job forms and license applications evince this social emphasis. ${ }^{56}$ Inevitably, few individuals and institutions distinguish among the various arrest contexts. Even the arrest records themselves may not accurately reflect the disposition of the case; nor will they recount special circumstances of the arrest, as in cases of unconstitutional dragnet arrests, constitutionally questionable mass arrests, arrests made for the purpose of harrassment, and arrests used as a show of force by the police. ${ }^{57}$ Even if these incidents of arrest constitute a small percentage of all arrests, they pose a very real problem to the individuals whose records and reputations are directly involved.

The well-recognized fact that many cases never make it past the arrest or

52. Pope, Postarrest Release Decisions: An Empirical Examination of Social and Legal Criteria, $15 \mathrm{~J}$. Research on Crime \& Deline. 35, 48 (1978).

53. Sullivan \& Siegel, supra note 31 , at 262.

54. For an extended discussion of the impact of the exclusionary rule, see Y. KamiSAR, W. LAFAVE \& J. IsRaEL, supra note 34 , ch. 11.

55. See Pope, supra note 52.

56. A typical job application form includes the question "Have you ever been arrested? Explain," without room for much more than the "Yes" or "No."

57. Goldstein, supra note 5, at 580 . 
indictment stage calls into question the meaningfulness of the records. There are substantial numbers of arrests which are terminated by release from police custody because the case is not strong enough, the effort needed to prosecute is not worth the return, or the police recognize a fatal illegality in their actions. ${ }^{58}$ In other cases, the prosecutor may decide to terminate the matter for similar reasons. In each of these circumstances, although the arrestee never goes to trial or pleads guilty, the record remains.

The maintenance of arrest records should have some empirically valid purpose in order to justify the records' negative consequences. Since arrest records are kept, at least theoretically, for valid law enforcement purposes, ${ }^{59}$ they should produce some tangible benefit to the criminal justice scheme. Ideally, the records should aid in detecting and predicting the incidence of criminality for those with prior arrests. In the absence of some such predictive validity, the records have purely arbitrary consequences since individuals immortalized in the records are associated with the "criminal files" regardless of their criminality. ${ }^{60}$

Data on the predictive value of arrest records are scant. ${ }^{61}$ Studies of arrests usually are tied to studies of convictions, making it difficult to ascertain

58. In one jurisdiction, it was found that the police released $50 \%$ of all arrestees at the stationhouse. See T. Ballinger, supra note 1 , at 31 .

59. See supra note 54 .

60. See T. Ballinger, supra note 1, at 51 ; see also United States v. Kalish, 271 F. Supp. 968,970 (D.P.R. 1967) (arrest records are part of "criminal" identification records).

61. Some general information on the significance and meaning of arrests is available in the area of parole prediction studies. Before discussing some of these studies, however, it is important to note that they suffer from one major flaw-they are geared toward determining whether potential parolees (i.e., persons convicted of a crime and incarcerated) are good parole risks. Consequently, the results may not be very instructive for the paradigmatic case posited in part II of this note. See supra notes 12-21 and accompanying text.

One general survey of the most widely used prediction models found that prior arrests were not considered a primary or important factor in developing a predictive scale. See Virginia Dep't of Corrections, Criminal Justice Prediction Scales (1978). Among the scales which attached significance to prior arrests, the longest period of time considered significant was five years-that is, if the individual was arrested more than five years prior to the arrest leading to incarceration, the arrest was not included as a predictive factor. In the NCCD Base Expectancy Scale (BES), being arrest-free for five or more years correlated to the highest positive score on a scale totalling 100 . Both scales are methods of predicting parole success with regard to the chances of rehabilitation or recidivism. The higher the score, the less likelihood of recidivism. Id. at 6.

Extensive studies of the California BES have been conducted by Donald Gottfredson, individually and with others. The early Gottfredson studies found that the percentage of nonrecidivists in a pool of parolees decreased with any previous arrest history, D. GoTTFredson, Base Expectancy IN THE California Institution for Women (Cal. Dep't of Corrections 1962), and that parole violators were likely to have had more prior arrests, commitments, and incarcerations. D. GotTrREDSON \& J. Bonds, A Manual for Intake Base Expectancy Scores (Cal. Dep'l of Corrections 1981). In another study, Gottfredson and Bonds made the salient point that at least some prior arrests without conviction have predictive validity since the reason no conviction appears might be that the prosecutor chose to conserve judicial resources by substituting penalites (for example, reincarceration on a parole violation rather than a trial on the new offense). D. GotTraedson \& J. Bonds, Systematic Study of Experience as an Aid to Decisions (Cal. Dep't of Corrections 1961). Despite the above studies, in a 1978 parole guidelines development project for the National Institute of Legal Education and Criminal Justice, Gottfredson (along with Leslie Wilkens) did not mention arrests as an "important" or "essential" element. D. Gottrredson \& L. Wilkins, Guidelines for Guideline Development, Classification for Parole Decision Policy (1978). 
the independent significance of either factor. While arrest records are said to have a valid law enforcement purpose, such a purpose has not been empirically demonstrated, and the justifications for the maintenance and use of these records consequently appear somewhat spurious.

The study of pretrial releases and preventive detention practices provides some information about the validity of prior arrests as a factor influencing judicial decisions. ${ }^{62}$ Preventive detention programs are designed to determine whether an arrested individual is potentially dangerous for purposes of denying bail or, in the other extreme, for permitting release on personal recognizance. Senator Sam Ervin, in his foreword to a study of preventive detention in the Harvard Civil Rights-Civil Liberties Law Review, found the practice of preventive detention both questionable in its effectiveness and constitutionally suspect. ${ }^{63}$ Senator Ervin found that none of the variable factorsincluding arrest records-was a reliable predictor of criminality, and that the practice of distinguishing among individuals on the basis of such factors raised equal protection and due process concerns. ${ }^{64}$

The Harvard study found that the ability to identify violent offenders, the ostensible goal of preventive detention, was not easily attainable. For example, if the Washington, D.C., preventive detention criteria were used in Boston, the identification of violent offenders would not have been affected significantly. ${ }^{65}$ Since the criteria included an analysis of past arrests, one possible conclusion is that such arrests do not indicate with sufficient certainty that individuals are more prone to criminality. Consequently, the entire practice of utilizing prior arrests as a factor in judicial decisions is of questionable value.

Law enforcement agencies continue to advocate the utilization of arrest records by police officers despite the fact that empirically based materials appear to discount the importance of prior arrests. ${ }^{66}$ The studies that do give

62. See, e.g., N. Bases \& W. McDonald, Preventive Detention in the District of Columbia: The First Ten Months (1972); Note, Preventive Detention, 6 Harv. C.R.-C.L. L. Rev. 300 (1971).

63. Ervin, Foreword: Preventive Detention-A Step Backward for Criminal Justice, 6 HARv. C.R.-C.L. L. REv. 291 (1971).

64. Id. at $295,298$.

65. See id. The Vera Foundation studies criminal justice processes and procedures and recommends modificaitons. See N. BASEs \& W. McDonald, supra note 62. The Foundation's finding that preventive detention is used infrequently leads to the conclusion that the need for such a device is minimal. In turn, the underlying bases-such as arrest records-for preventive detention decisions are also suspect since they should be the rationale for the detention of an individual. See id. at 72 . The Foundation also poses the question whether preventive detention programs may lead to overcharging. See id. at 95 . Overcharging leads to even greater unfairness to individuals with arrest records.

Bail systems test the theoretical constructs governing treatment of individuals arrested but not yet tried. In this regard, the factors used to determine eligibility for bail should track those characteristics which most strongly indicate a high degree of risk. For example, in the Vera Foundation's Manhattan Bail Project, prior arrests are not a consideration in determining eligibility for the program. Rather, the project concentrates on prior convictions and the nature of the crimes underlying the convictions. See D. Freed \& P. Wald, Bail in the United States 56-59 (1964).

66. See supra notes 47-49 and accompanying text; see also D. GoTTFREdSON \& K. BALLARD, REPORT No. 4 (Institute for the Study of Crime and Delinquency 1964) (stating that there is a consensus in some circles that prior arrests are a "quite important" factor for parole predictions). 
some significance to these arrests are older and many have been supplanted by newer studies reaching opposite conclusions. This conflicting information makes the policymaker's decision as to how to reevaluate the use of arrest records a difficult one indeed.

\section{VI}

\section{The Implications of Permitting the Use of Arrest Records}

The cases which comprise the factual details of arrest records are subject to a wide array of dispositions involving no finding of guilt, ranging from release without charging to acquittal. Although the contexts in which arrestees are released vary, the records all carry the same implications. Consistent with this concern, one court has declared:

For the person who has been arrested and exonerated, the presumption of innocence is lost. He stands at a distinct disadvantage to other, also presumably innocent, citizens who do not have a 'record.' Though he has been found innocent of any wrongdoing, the record will remain as a cloud over his future, put there and maintained by the same system of justice that exonerated him. ${ }^{67}$

The "cloud" extends because, while the courts are governed by a presumption of innocence, societal attitudes are not. An arrest is "distinct from other interactions between citizens and police" because it is the first stage of a potential criminal prosecution. ${ }^{68}$ Consequently, the existence of an arrest record in this society suggests guilt, even when the individual is not found guilty. ${ }^{69}$ Courts exacerbate the problem by generally providing remedies, such as expungement, only to those who affirmatively prove their innocence. ${ }^{70}$ For all practical purposes, as far as the use of records is concerned, an arrest is equivalent to a conviction. The traditional presumption of innocence loses meaning, even in the courtroom, ${ }^{71}$ and the innocent individual who falls by chance into the criminal justice system suffers many of the same disabilities as the career criminal. The individual may even have to relive this traumatic event, if cross-examined about it as a witness in a subsequent trial..$^{72}$

The case law and literature are replete with examples of individuals suffering from the mere fact of having a record of arrest. Some of the most noteworthy cases arise in the areas of jobs ${ }^{73}$ and licensing. ${ }^{74}$ Moreover, the individual arrested suffers from a social stigma. This, admittedly, cannot be

67. United States v. Singleton, 442 F. Supp. 722, 724 (S.D. Tex. 1977).

68. Menard v. Saxbe, 498 F.2d 1017, 1029 (D.C. Cir. 1974).

69. See Hess \& Le Poole, Abuse of the Record of Arrest Not Leading to Conviction, 13 CRIME \& DelinQ. 494, 495-96 (1967).

70. See supra note 19 and accompanying text.

71. One recent study reported in the popular press found that the fact that a defendant has been arrested and is standing trial will cause juries to lean toward a guilty verdict. The study, conducted by Norman Bregman, found that people believe that the initial trial of someone suggests that the "guy must be guilty of something." Durham Morning Herald, Aug. 26, 1984, at 14A.

72. Michaelson v. United States, 335 U.S. 469, 483-84 (1948).

73. Courts are aware of the potential for lost economic opportunities for youths who have arrest records. See, e.g., Doe v. Webster, 606 F.2d 1226, 1234-38 (D.C. Cir. 1979). Applications for jobs will often inquire about arrests and a record will frequently be "a substantial barrier to employment." Menard v. Saxbe, 498 F.2d 1017, 1024 (D.C. Cir. 1974). Economic opportunities are lost as 
erased by the mere sealing or expungement of records. ${ }^{75}$ Most important, though, the fact that an individual has been arrested makes him a likely candidate for future police contacts. On this point, the Colorado Supreme Court remarked: "[I]t is common knowledge that a man with an arrest record is much more apt to be subject to police scrutiny-the first to be questioned and the last eliminated as a suspect in an investigation. If he is subsequently arrested, his arrest record may arise to haunt him . . . "76 A vicious cycle for the individual may thus begin; each subsequent arrest adds to the suspicion with which authorities regard the individual. The virtual absence of a means of eliminating these records, given the paucity of expungement procedures, amounts to a terminal commitment of the individual to the criminal justice system. ${ }^{77}$

Some may argue that police behavior like that described above is a completely reasonable response. This proposition is dubious, however, in light of the fact that the targeted individual may never have been convicted of a crime and might have been the victim of a mistaken identification or, worse yet, a malicious investigation. Police discretion influenced by this type of information is misguided and out of place in a society that extols the virtues of due process. Admittedly, discretion has a role in the enforcement of laws; nevertheless, its exercise should not be based on grossly misleading information. When officers exercise discretion in a system based on stored information which is possibly incorrect, rather than on their own perceptions of events,

a result of the mere fact of arrest; subsequent acquittal does not seem to remove the stigma. See Menard v. Mitchell, 430 F.2d 486, 490 (D.C. Cir. 1970), on remand, 328 F. Supp. 718 (D.D.C. 1971).

74. See Menards v. Saxbe, 498 F.2d 1017, 1024 (D.C. Cir. 1974). Applications for professional licenses will often inquire into the arrest history of an individual. In professions which strictly scrutinize the "morals" of an individual, as is the practice of many state bar associatons, it seems very likely that an arrest record could have a deleterious effect on an individual's application to practice within the profession.

75. See supra note 19 and accompanying text.

76. Davidson v. Dill, 180 Colo. 123, 127, 503 P.2d 157, 159 (1972) (citing United States v. Cifarelli, 401 F.2d 512 (2d Cir. 1968)). Harm in noncriminal contexts involves the poetntial for termination of employment or refusal of employment, lowered credit ratings, and a general social stigma. In the "criminal context," the arrestee is subject to greater scrutiny because he is known to the police, who maintain physical records about the individual. As a consequence, the individual loses a great deal of his privacy: "An individual who has been arrested and then acquitted has an undeniably greater visibility to the police than other persons. His fingerprints, and more particularly his photograph, are available to be shown to other citizens as a potential suspect to be chosen in prearrest lineups . . . ." Eddy v. Moore, 5 Wash. App. 334, 344, 487 P.2d 211,216 (1971). This scrutiny is increased when the arrestee is alleged to have used a particular modus operandi or has a unique physical characteristic. Moreover, in close cases, the fact of a prior arrest may tip the scales, irrespective of the probable cause considerations, toward making an arrest: "An arrest record may be used by the police in determining whether subsequently to arrest the individual concerned, or whether to exercise their discretion to bring formal charges against an individual already arrested." Menard v. Mitchell, 430 F.2d 486, 490-91 (D.C. Cir. 1970).

77. As one court noted, "Although never found guilty of a crime, the constitutional benchmark to the infliction of punishment, a person who becomes entangled with the criminal justice system is forever unable to extricate himself even if completely exonerated." United States v. Benlizar, $459 \mathrm{~F}$. Supp. 614,619 (D.C. Cir. 1978). This result seems unacceptable in light of another court's conclusion that "a collection of dismissed, abandoned or withdrawn arrest records are no more than gutter rumors when measured against any standards of constitutional fairness to an individual ....." United States v. Dooley, 364 F. Supp. 75, 77 (E.D. Pa. 1973). 
there is great potential for harm to the individual who has no effective way to counteract the source of information. ${ }^{78}$

The problems associated with arrest records are likely to expand in the wake of increasing computerization and ease of access to data banks. ${ }^{79}$ The NCIC files are accessible to law enforcement agencies nationwide and many states are now also maintaining extensive files. ${ }^{80}$ Modern computers allow information to be conveyed to the officer in the field almost instantaneously. Eventual reliance on computer consoles in police cars does not seem unrealistic. Obviously, this procedure would be useful and appropriate for determining the existence of outstanding warrants and related items; however, arrest record information would also be easily accessible. Given the prejudicial nature of arrest records, limiting access to them may be an appropriate response.

The issue of access is fundamentally one of value choices. Cogent arguments are made to justify easy access to arrest records by police officers. Despite the difficulty in empirically demonstrating the validity of these arguments, law enforcement authorities are understandably concerned that they not be cut off completely from this type of information. On the other hand, law enforcement authorities who think they have a need for these records cannot simply abrogate the interests of innocent individuals. Consequently, solutions accounting for the interests of both individuals and law enforcement agencies are required.

\section{VII}

\section{Conclusion: Some Questions, Some Answers, Some Unknowns}

The reference to arrest records in the NCIC system as "criminal records" 81 is indicative of the prevalent perception of the meaning of arrests. Knowing that this perception is widespread, law enforcement agencies have a responsibility to ensure that the records themselves do not further distort. Law enforcement agencies must, at a minimum, act to ensure that the records are accurate and up-to-date; this should include, at least, noting the dispositions of prior arrests. Unfortunately, this is no easy task, given the multitude of jurisdictions and the widespread confusion over the responsibility for the accuracy of records. ${ }^{82}$

78. See Murphy, supra note 7, at xi. Murphy also briefly discusses the privacy issues relating to arrest records and instantaneous access by police officers in the field. Id. This dimension of the problem merits further study, but is beyond the scope of this note.

79. See Benlizar, 459 F. Supp. 614, 619 (D.C. Cir. 1978).

80. In California, 1.5 million arrest records are created every year. T. BALLINGER, supra note 1 , at 31 . Most states maintain a bureau responsible for the maintenance of criminal records and related materials.

81. United States v. Kalish, 271 F. Supp. 968, 970 (D.P.R. 1967).

82. The FBI maintains centralized criminal record files and receives its information from federal, state, and local law enforcement agencies. The FBI generally is not responsible for correcting the information received unless the supplying agency forwards to it the corrected information. McKnight v. Webster, 499 F. Supp. 420, 422-23 (E.D. Pa. 1980). The FBI is only responsible for correcting files on its own when the information is obviously incorrect. Shadd v. United States, 389 
To address properly the issues surrounding the impact of arrest records on the exercise of police discretion, an attempt to answer the following empirically based questions must be made:

1. How significant is the existence of a prior arrest record in the decision to detain or arrest an individual suspected of a crime (i.e., how do arrest records interact with other factors affecting discretion)?

2. How does the predictive validity of the prior arrest record compare with other potential criteria which influence the exercise of discretion?

3. What probative value do prior arrests have in terms of past or future criminality?

4. What predictive value do prior arrests have with respect to the future criminality of persons convicted of a crime?

The answers to these questions will influence the value choices made with respect to the latitude police have in making arrest decisions. Unlike the suggestions that records be complete, accurate, and up-to-date, which are likely to raise only administrative concerns, attempts to restrict the accessibility of arrest records to law enforcement agencies and/or officers in the field will receive strong opposition. A starting point for the debate may be the differentiation between arrests and convictions, since the latter have much greater significance. Nonetheless, even prior convictions may not always be either very informative (when pardon has been granted, for example ${ }^{83}$ ) or a valid influence in deciding whether a suspect committed a present offense. For the paradigmatic case of the individual who is arrested but is neither convicted nor the beneficiary of a preprosecution diversion program, ${ }^{84}$ however, the problem of prior convictions or diversions is obviously not a factor. While no numbers are available on this specific cohort, given the millions of arrests and the multiplicity of record-keeping entities, it is likely that the group is quite large.

Three alternatives to the status quo are possible and workable. First, records with arrests but no convictions could be expunged. Unfortunately, while this alternative is the best approach for the arrestee, it is the most unlikely to be accepted by police authorities. Second, a time limit-five years, for example-could be placed on the maintenance of records of prior arrests in active files. Thereafter, the records would be either sealed or expunged. In the event of sealing, the records would be available only after subsequent arrests. The time period would match the length of arrest-free periods thought significant by the various parole predictive studies, ${ }^{85}$ which offer a basis of comparison with a known standard. The time period might be shorter for records containing only arrests than for those also containing convictions.

F. Supp. 721,724 (W.D. Pa. 1975), affd without opinion, 535 F.2d 1247 (3d Cir.), cert. denied, 429 U.S. 887 (1976). Thus, if a local agency fails to provide updated information to the FBI, the files at the FBI may differ from the state or local files. This problem is exacerbated by the fact that state and local agencies often maintain separate files.

83. See People v. Glisson, 44 Ill. App. 3d 108, 358 N.E.2d 35 (1976), affd in part, rev'd in part, 69 IIl. 2d 502, N.E.2d 669 (1978) (pardoned individual treated as if never convicted). But see City of St. Paul v. Froysland, 310 Minn. 268, 246 N.W.2d 435, 438-39 (1976) (pardon does not eliminate occurrence of conviction and thus record can be used).

84. See supra p. 289.

85. See supra note 66 . 
The third alternative is to restrict the availability of the arrest records within police departments. Only senior administrators would have access to the information and the various data bases containing the information could be programmed with this restriction. By eliminating the accessibility of the records to officers in the field, there would be less likelihood that this information would constitute part of a probable cause determination. Distinctions could be made between records with arrests only and those with convictions, with the latter being made more accessible. The objective of this alternative would be to channel discretion in a manner which gives greater weight to observed or investigatively determined factors than to external information sources of questionable reliability. This alternative would also give police administrators greater control.86

The efficacy of these solutions is only provable with longitudinal studies which track the nature of the exercise of discretionary authority in the field and which, as done in Bellevue, seek to break out the factor of prior arrests from other potential situational determinants. These studies should seek to answer the questions posed earlier in this note concerning the predictive value of the records. In light of these studies, though, there will be a continuing need to decide whether society wishes to move along the continuum toward either the Due Process model or the Crime Control model. While the outcome of these studies will not be determinative as to the direction chosen, the studies will permit a more informed discussion and will help guide the debate towards a rational balance between the legitimate concerns of law enforcement agencies and the constitutional guarantees underlying the criminal justice system.

86. Actually, a fourth alternative exists which is concerned with general police authority. This approach would give police agencies greater leeway to release individuals after charging when no further evidence is developed. While at first this plan might appear to increase discretion in a less palatable manner, such a device, if coupled with appropriate rules, might channel police discretion more effectively. If combined with a rule requiring accurate notations on the records as to the reasons for release, fewer ambigious records would result and individuals would, at least, have the benefit of a potentially expedited system. While complete discussion of this alternative is beyond the scope of this note, the fourth option is mentioned to suggest the existence of a myriad of creative and potentially effective alternatives to discretion based on presently questionable criteria. See also Uviller, supra note 29, at 315 (discussion on the related concept of the individual officer's authority to decline to arrest when he has an articulable reason for taking this course). 